\title{
Green Banking Practices in Bangladesh: A Critical Investigation
}

\author{
Nazamul Hoque ${ }^{1}$, Md. Masrurul Mowla ${ }^{1}$, Mohammad Shahab Uddin ${ }^{2}$, Abdullahil Mamun ${ }^{1} \&$ \\ Mohammad Rahim Uddin ${ }^{3}$ \\ ${ }^{1}$ Associate Professor, Department of Business Administration, International Islamic University Chittagong, \\ Bangladesh \\ ${ }^{2}$ Associate Professor, Department of Management, University of Chittagong, Bangladesh \\ ${ }^{3}$ Assistant Professor, Department of Business Administration, International Islamic University Chittagong, \\ Bangladesh \\ Correspondence: Nazamul Hoque, Associate Professor, Department of Business Administration, International \\ Islamic University Chittagong, Bangladesh. E-mail: nazam_iiuc@yahoo.com
}

Received: January 17, 2019

Accepted: February 14, 2019

Online Published: February 15, 2019

doi:10.5539/ijef.v11n3p58

URL: https://doi.org/10.5539/ijef.v11n3p58

\begin{abstract}
Green banking or sustainable banking is one of the issues of the concern of all stakeholders of the world. Following this concern, this study has investigated the status of green banking practices of the non-bank financial institutions (NBFIs) and commercial banks of Bangladesh. Analyzing the contents of annual reports as well as websites of banks and NBFIs, the study finds that 44 out of 57 banks and 13 out of 33 NBFIs, to a varying degree, have exposures in direct or indirect green financing. But only 45 banks and 25 NBFIs conducted environmental risk rating. Most of the banks and NBFIs practice green banking only in a limited scale and volume and disclose green banking information in a semi structured manner in both the annual reports and corporate websites. However, except one, all the 56 scheduled banks and all the 33 non-bank financial institutions (NBFIs) have their own green banking policy guidelines. They also have green office guide for conducting in-house green activities. The study finds that green banking disclosures in their annual reports exceed that in their websites. It is also found that both private commercial banks (PCBs), and foreign commercial banks (FCBs) have surpassed state-owned commercial banks (SCBs) and state-owned specialized development banks (SDBs) in terms of the green financing.
\end{abstract}

Keywords: green financing, green safety, sustainability, ecological balance

\section{Introduction}

The banking activities that help on the whole the lessening of internal carbon footprint and external carbon emission can be considered as green banking (Lalon, 2015; Sahoo \& Nayak, 2008; Bahl, 2012). Green banking is an effort to make the industries grow green and in the process restore the natural environment with a view to ensuring green safety and sustainable ecological balances (Bhardwaj \& Malhotra, 2013). As a part of green banking initiative the banks and NBFIs adopt environmental friendly financing mechanism as well as green transformation of internal operations (Bahl, 2012; Rahaman et al., 2015). United Nations Environmental Program (UNEP, 2014) defines green economy/banking as "one that results in improved human well-being and social equity, while significantly reducing environmental risks and ecological scarcities". Within the framework of green banking concept, a company is awarded loan only when all the environment safety standards are followed. This concept is mutually beneficial to the banks, industries, and economy (Dharwal \& Agarwal; 2013; Weber et al., 2015; Shaumya \& Arulrajah, 2016). The greening of industries can be ensured through green banking because bank as financier has huge influence on the projects undertaken by industries and thereby green banking can play significant role in ensuring responsible behavior of other businesses too (Sahoo \& Nayak, 2008; Bihari \& Pandey, 2015; Nisha, 2016).

Recently, the green banking movement has influenced banking sector of Bangladesh mostly due to green policy framework of the central bank of Bangladesh. The banks in Bangladesh are practicing green banking more or less along the lines of the policy framework of Bangladesh Bank, the central bank of Bangladesh. To reveal the nature and extent of green banking practices in Bangladesh many researches (Ullah, 2013; Ahmad et al., 2013; Islam \& Das, 2013; Masukujjaman \& Aktar, 2014; Rahman et al., 2015; Islam, 2014; Islam et al., 2014; Roy, 2015; 
Islam \& Hasan, 2015; Shakil et al., 2014; Ahsan \& Uddin, 2015; Rifat et al., 2016) made efforts but could not explore in detail the nature, extent and impacts of green baking practices in the country. Furthermore, no study applied content analysis approach for understanding and identifying the depth and breadth of green banking practices. Therefore, this study is an initiative to meet this research gap.

\section{Literature Review}

Muhamat and Nizam (2010) reported that the concept of "ethical banking is gradually receiving attention and acceptance from the depositors and investors who are not only searching for a place to save and invest their money safely, but also a place where their money will be channeled to productive activities which are free from elements that contribute to the deterioration towards standard of living and environmental aspects." Bihari (2010) observed that Indian banks conceived the necessity of environmental and societal roles of banking while operating banking activities.

Bangladesh Bank, took initiative to ensure green banking practices among the scheduled commercial banks of Bangladesh. As part of that drive and initiative, a policy guideline was framed and issued to the scheduled banks in February 2011, and to NBFIs in August 2013 and to the new banks in September 2013. Despite it, the practice of green banking is really in its infancy in Bangladesh. Masukujjaman and Aktar (2014) observed that the banking sector is at initial stage in understanding and practicing the green banking and they are far behind their counterparts from developed countries. They observed that only very few commercial banks are doing in in-house environment management in volume and scale and contributing significantly to the sustainable financing. Hossain et al. (2016) found in their study that some of the sample banks only presented a general statement without having detailed information with specific quantitative information. There are some other studies undertaken with a view to portray the green banking scenario in Bangladesh (Ullah, 2013; Ahmad et al., 2013; Islam \& Das, 2013; Masukujjaman \& Aktar, 2014; Rahman et al., 2015; Islam, 2014; Islam et al., 2014; Roy, 2015; Islam \& Hasan, 2015; Shakil et al., 2014; Ahsan \& Uddin, 2015; Rifat et al., 2016). But, no study is found that comprehensively investigated the green banking practices in Bangladesh. Almost, all studies designed their methodology taking some sample banks without considering all the banks and NBFIs of Bangladesh. Therefore, by covering all the banks and NBFIs and employing content analysis approach and in-depth interview, this research is an initiative to explore the nature and extent of sustainable banking operations in Bangladesh.

\section{Methodology of the Study}

In this research, mainly content analysis has been applied because of the fact that this method has become one of the most popular choices among the environmental accounting and social science researchers. Content analysis is a detailed, careful, systematic interpretation and examination of a particular body of material conducted with a view to examine and identify themes, patterns, meanings and biases (Berg \& Lune, 2012; Weber, 1990; Krippendorf, 2004). In content analysis, content of text, speech, interviews, images etc. are classified and categorized. However, the content analysis in this study is confined to the annual reports, and websites of 57 Banks and 33 NBFIs in Bangladesh. Thus, this study examined websites and annual reports of banks and NBFIs in order to identify the several green banking issues that were disclosed. From 2011, all the sample banks and NBFIs started reporting under the heading of 'Green Banking' and 'green financing'. So, the contents under these headings were analyzed. By keeping these issues in mind, the content analysis was conducted under a descriptive framework to identify the nature and extent of overall green banking practices in Bangladesh.

Furthermore, this study has considered the green banking framework (see appendix: Figure 1) as well as suggested green financing schemes (see appendix: Figure 2) of Bangladesh Bank, to evaluate the green banking practices of banks and NBFIs in the country. Recently, Bangladesh Bank has widened the number of green Products under several refinance schemes to widen their outreach in green financing. Now, 50 green products are being offered in 11 categories.

The study has also collected the necessary cross-sectional data interviewing the relevant policy makers and monitoring authority of different stakeholders such as city corporation commissioner, administrator, representative of environmental ministry, bankers, representative of central bank, media representative etc, to settle the debate regarding green banking issues. This is due to the fact that green banking management performance is the outcome of integrated efforts of different stakeholders and bodies.

\section{Findings and Analysis}

The analyses of the contents and the results have been presented and discussed according to sections and theme of study as below: 


\subsection{Direct Green Finance /Investment}

It is found that 33 out of 57 banks and 10 out of 33 NBFIs have had exposures in direct green finance within the framework of green banking. As part of direct green investment and financing initiatives loans are provided too many noncompliance garment factories to convert them into environmentally complied factory as per observation of 'accord' and 'alliance' (associations of buyers) and so on. A good number of banks mentioned in their annual report that they financed many projects for establishing environmental friendly industry and transforming existing traditional ones into green ones such as financing to install waste treatment plant (ETP) in textiles, RMG, tannery, ship breaking etc. Even, many banks and NBFIs financed the businesses to produce green products. Some banks reported that clearance is taken from the department of environment of the government before giving sanction to any new project. It has been found that in the financial year 2016, 46 banks and NBFIs of Bangladesh, disbursed total amount of Taka 33358.2 million as direct green finance. Sector-wise contribution of the total direct green finance shows (see Table 1) that the private commercial banks (PCBs) played the main role (73.74 percent) followed by NBFSs (17.83 percent), state-owned commercial banks (SCBs) (6.04 percent), Foreign commercial banks (FCBs) (2.30 percent), and state-owned specialized development banks (SDBs) (0.09 percent). Regarding the product-wise financing it is seen (Table 2) that Fire burnt brick has received the highest $(21.46 \%)$ amount and solid waste management received lowest amount $(0.04 \%)$.

Table 1. Volume of direct green finance in the year 2016 banks and NBFIs (in million Taka)

\begin{tabular}{ccc}
\hline Type of banks/NBFIs & Direct Green finance(TK in Million) & Sector wise contribution \\
\hline $\operatorname{SCBs}(06)$ & 2013.7 & $6.04 \%$ \\
$\operatorname{SDB}(02)$ & 30.1 & $0.09 \%$ \\
$\operatorname{PCB}(40)$ & 24597.4 & $73.74 \%$ \\
$\operatorname{FCBs}(09)$ & 768.8 & $2.30 \%$ \\
NBFIs(33) & 5948.2 & $17.83 \%$ \\
Total & $\mathbf{3 3 3 5 8 . 2}$ & $\mathbf{1 0 0 \%}$ \\
\hline
\end{tabular}

Source: Bangladesh Bank.

Note. Figure in the parenthesis indicates the number of institutions.

SCBs $=$ State-owned commercial banks, SDBs $=$ State-owned specialized development banks, PCBs $=$ Private commercial banks, FCBs $=$ Foreign commercial banks, NBFIs $=$ Non-bank financial institutions.

Table 2. Volume of green finance products of banks and NBFIs in the year 2016 (in million Taka)

\begin{tabular}{lccccccc}
\hline Green finance products & SCBs & SDBs & PCBs & FCBs & NBFIs & Total & Percentage \\
\hline Renewable energy & 44.4 & 4.2 & 1605.0 & 182.0 & 3660.2 & $\mathbf{5 4 9 5 . 7}$ & $16.47 \%$ \\
Energy efficiency & 10.1 & 0.0 & 2394.3 & 0.6 & 125.3 & $\mathbf{2 5 3 0 . 3}$ & $7.58 \%$ \\
Solid waste management & 0.0 & 0.0 & 12.2 & 0.0 & 0.0 & $\mathbf{1 2 . 2}$ & $0.04 \%$ \\
Liquid waste management & 26.3 & 0.0 & 4326.5 & 36.2 & 449.0 & $\mathbf{4 8 3 8 . 0}$ & $14.50 \%$ \\
Alternative energy & 160.0 & 0.0 & 164.8 & 0.0 & 9.2 & $\mathbf{3 3 4 . 0}$ & $1.0 \%$ \\
Fire burnt brick & 1003.8 & 25.3 & 5353.9 & 0.0 & 775.0 & $\mathbf{7 1 5 7 . 9}$ & $21.46 \%$ \\
Non fire block brick & 0.0 & 0.0 & 169.8 & 0.0 & 40.0 & $\mathbf{2 0 9 . 8}$ & $0.63 \%$ \\
Recycling \& recyclable product & 99.1 & 0.0 & 4179.6 & 80.0 & 518.8 & $\mathbf{4 8 7 7 . 4}$ & $14.62 \%$ \\
Green industry & 380.0 & 0.0 & 4106.2 & 283.6 & 256.0 & $\mathbf{5 0 2 5 . 8}$ & $15.07 \%$ \\
Safety and security of factory & 0.0 & 0.0 & 1817.1 & 34.8 & 95.5 & $\mathbf{1 9 4 7 . 4}$ & $5.85 \%$ \\
Others & 290.1 & 0.6 & 467.9 & 151.7 & 19.3 & $\mathbf{9 2 9 . 6}$ & $2.78 \%$ \\
Total & $\mathbf{2 0 1 3 . 7}$ & $\mathbf{3 0 . 1}$ & $\mathbf{2 4 5 9 7 . 4}$ & $\mathbf{7 6 8 . 8}$ & $\mathbf{5 9 4 8 . 2}$ & $\mathbf{3 3 3 5 8 . 2}$ & $\mathbf{1 0 0 \%}$ \\
\hline
\end{tabular}

Source: Bangladesh Bank.

\subsection{Indirect Green Financing}

It is found that in terms of indirect green financing the exposure is not satisfactory. Only 50.87\% banks (29 out of 57 banks) and $21.21 \%$ (7 NBFIs out of 33) have had disclosure in indirect green finance. They are approving working capital support to projects having effluent treatment plant (ETP) and environment friendly plants /industry/products to carry out their businesses. It has been found that in the financial year 2016, 469863.1million as indirect green finance. Regarding the sector-wise contribution (Table 3) the study finds that PCBs played the key role ( 80.85 percent) followed by FCBs (16.51 percent). Unfortunately, the role of SCBs is very insignificant $(0.26$ percent $)$ in this regard. 
Table 3. Volume of indirect green finance by banks and NBFIs in the year 2016 (in million Taka)

\begin{tabular}{ccc}
\hline Type of banks/NBFIs & Indirect green finance & Sector wise contribution \\
\hline $\operatorname{SCBs}(06)$ & 1234.5 & $0.26 \%$ \\
$\operatorname{SDBs}(02)$ & 0.0 & $0.00 \%$ \\
$\operatorname{PCBs}(40)$ & 379887.5 & $80.85 \%$ \\
$\operatorname{FCBs}(09)$ & 77547.3 & $16.51 \%$ \\
$\operatorname{NBFIs}(33)$ & 11193.8 & $2.38 \%$ \\
Total & $\mathbf{4 6 9 8 6 3 . 1}$ & $\mathbf{1 0 0 \%}$ \\
\hline
\end{tabular}

Source: green banking repot, Bangladesh Bank.

\subsection{Environmental Risk Rating and Management}

Almost all banks and NBFIs have developed environmental risk management guidelines as per the prescribed framework of Bangladesh Bank. It is also observed that more or less, all banks consider both investment risk Management and environmental risk management while financing the project. In many cases, risk of environmental has been integrated with credit appraisal procedure of banks. At the end of the year 2016 is found that 60175 projects have been rated (see Table 4) and 52776 projects $(87.70 \%)$ have been financed by banks. Banks have disbursed Tk. 2242757.80 million for these projects, of which PCBs contributed $86.71 \%$, FCBs contributed $6.01 \%$ and SCBs and SDBs contributed very minimum amount. Regarding the environmental risk rating one of the managers of private commercial bank replied.

Table 4. Environmental risk rating of banks and NBFIs in the year 2016

\begin{tabular}{cccccc}
\hline $\begin{array}{r}\text { Type of } \\
\text { banks/NBFIs }\end{array}$ & $\begin{array}{c}\text { No. of projects } \\
\text { applicable for EDD }\end{array}$ & $\begin{array}{c}\text { No. of projects } \\
\text { rated }\end{array}$ & $\begin{array}{c}\text { No. of rated } \\
\text { projects financed }\end{array}$ & $\begin{array}{c}\text { Amount disbursed in rated } \\
\text { projects (million Taka) }\end{array}$ & $\begin{array}{c}\text { Percent of } \\
\text { disbursed amount }\end{array}$ \\
\hline SCBs(06) & 2154 & 1967 & 1916 & 48404.30 & $2.17 \%$ \\
SDBs(02) & 49 & 38 & 50 & 2354.10 & $0.10 \%$ \\
PCBs(40) & 62371 & 52182 & 46531 & 1944815.50 & $86.71 \%$ \\
FCBs(09) & 3240 & 2974 & 1717 & 134839.30 & $6.01 \%$ \\
NBFIs(33) & 2893 & 3014 & 2562 & 112344.70 & $5.01 \%$ \\
Total & $\mathbf{7 0 7 0 7}$ & $\mathbf{6 0 1 7 5}$ & $\mathbf{5 2 7 7 6}$ & $\mathbf{2 2 4 2 7 5 7 . 8 0}$ & $\mathbf{1 0 0 \%}$ \\
\hline
\end{tabular}

Source: Bangladesh Bank.

We are always concerned about environmental risk rating because of our CSR commitment and our commitment to the country as well. It is our management policy that not a single project will be financed without environmental risk rating (Interviewee 1, Executive vice president and Head of sustainable banking, Private commercial bank).

However, the civil society leader raised his concern about the intention of the bankers stating that,

A few banks are sincerely committed to comply with green banking policy framework of Bangladesh bank. They are always concerned for profit not environment. Central bank as a monitoring authority is not playing functional and effective roles in this regard. Our concerned ministry is simply sleeping. It is our bad luck! (Interviewee 7, University teacher and president of a NGO).

Regarding the environmental risk rating the representative of central bank of Bangladesh expressed his views. He opined that

We have provided the policy framework and we are also monitoring the banks and NBFIs in terms of environmental risk rating. Those who are blaming us they have poor knowledge or wrong information about us. However, we are to be more concerned regarding performance evaluation of the banks and NBFIs. (Interviewee 3, GM, Bangladesh bank).

The respondent of environment office replied,

We have policy but there is a problem of proper monitoring. We are concerned and paying our attention towards the issue (Interviewee 4, officer, environment office of Bangladesh)

The representative of printing media (daily news paper) replied that,

We always try to develop awareness among the different stakeholders about the different social issues. But, state agencies are not necessarily active and supportive in taking fruitful action to solve the problem. However, we 
should also play more active roles in developing awareness (Interviewee 6, Staff reporter, Daily newspaper)

\subsection{Green Marketing, Awareness Development, and Supporting Green Events}

Most of the banks and NBFIs formed green banking unit and / or sustainable finance department following the sustainable financing guidelines of central bank of Bangladesh. Many banks and NBFIs have already launched green office guide highlighting the efficient uses of resources and accordingly circulated among all branches. The green banking disclosures and annual reports of different banks covered their green marketing and awareness development activities in diverse ways and centering the following (Figure 3) activities. In the year 2016, banks used Taka 53.5 million for green marketing and NBFIs used Taka 2.7 million for that cause.

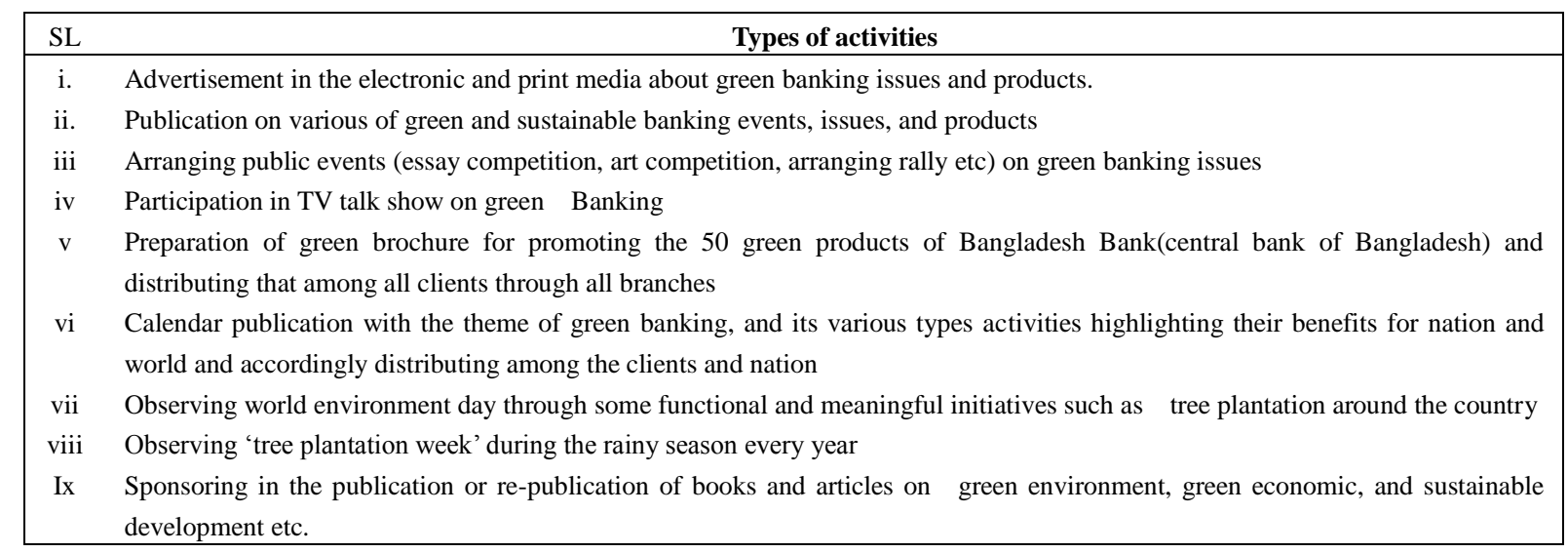

Figure 3. Various types of green awareness development, and supporting activities

Source: compiled by the authors on the basis of annual reports and corporate websites.

\subsection{Green Training and Capacity Building}

Many banks and NBFIs report that they organize pertinent and essential training and development programs like seminars, symposiums, discussion meetings, and workshops on environmental risk management and green banking are organized. Some banks reported that their employees also participate time to time in many training programs organized by other institutions relating to the theme of sustainable/green banking issue. However, the banks did not categorically mention the number of training programs organized for ensuring green banking practices. It is also not mentioned that whether those training programs were effective in terms of objective achievement. Regarding the effectiveness of training program one manager of private commercial bank replied that,

Every year we organize sufficient number of training program for the managers and concerned officer with a view to develop awareness and to improve the skills about it. (Interviewee 1, Executive vice president and Head of sustainable banking, Private commercial bank).

However, regarding the effectiveness of the training program the bankers themselves have expressed their concerns stating that "It is really tough to make the training program effective due to multi dimensional challenges. (Interviewee 5, Deputy managing director, and Head of corporate investment, Private commercial bank)".

\subsection{In-House Environmental Management}

The banks and NBFIs are practicing in-house green banking in many ways. The study summarized the different activities under the following themes;

i. Reducing utility consumptions: measures are being taken for reducing the consumption of water, electricity, fuel etc. As part of it, the number of branches powered by solar energy stood at 493 at the end of 2016 which was 416 at the end of the previous fiscal year. One NBFI reports that it has attained LEED (Leadership in Energy and Environmental Design) Gold Certification as first Bangladeshi financial institution from USGBC (United States Green Building Council) under the category of commercial interior.

ii. Reducing Paper \& stationary consumption: In order to reduce the paper and stationary consumption different banks have introduced the concept of soft archival of customer documents. Under this system electronic access and retrieval is enabling to reduce paper consumption. Now, most of the process notes, internal memos, 
and records are in electronic form. Communications with customers are almost being done through SMS emails, or ATM display instead of letter communication. IP phone with video conferencing system has been introduced for telecommunication between the officials of the Bank, practicing double side printing of papers, sending softcopies of statements through email whenever possible rather than sending hard copies, processing documents electronically using scan option on a copier when appropriate rather than printing hard copies. Eco-font printing to reduce the use of ink and paper use scrap paper as notepads, use of bio-metric attendance sheet, arranging paperless Credit Review Committee meeting (both SME \& Corporate) by soft copy presentation.

iii. Waste management: Still most of the banks didn't involve in waste management. A few banks and NBFIs report that they collect and dispose centrally both solid waste and e-wastes generated by their different units of operations through e-tendering with a view to ensuring an environment which would be free from pollution.

iv. Renewable energy: Almost all the banks and NBFIs report that they have started installation of solar panels at ATM booths/Fast Tracks and in many Branches (partially) including Head Office. Many banks reports that they use energy saving bulbs, energy efficient electronic equipments in offices, and share printers and photocopy machines.

v. Green travel: Initiatives have been taken to encourage the employees to undertake Green travel for personal as well as business travel and has the arrangements of hybrid autos and car pooling system.

vi. Ethical banking: Some banks and NBFIs developed policy not to finance enterprises which are involve in unethical businesses. However, this practice is not found so vibrant and wide spread. Even, there is allegation against many private and government commercial bank that they finance in many projects violating compliances. In this regard one banker of private sector replied,

It is true that due to political pressure we are unable to comply with the banking rules and regulation and also the green banking policy framework (Interviewee 5, Deputy managing director, and Head of corporate investment, Private commercial bank)

\subsection{Online Banking Practices}

State-of-the art technology is being used by many banks to provide various banking services without using paper such as Mobile banking, internet banking, ATM/Fast Track, SMS banking, phone banking, Credit Card, Debit Card, Call centre, E-payment, Virtual card, e-payment gateway facilities and so on. Some banks are centralizing their corporate credit operations and preserving the different security documents of clients in the 'central vault' as an initiative of green banking practices and thereby paper consumption is reduced along with reducing the wastage of valuable time. At the end of fiscal year 2016, 56 out of 57 banks had online branches and the number of online branches increased from 68.1 percent to 75.1 percent making $7 \%$ increased.

\subsection{Green Strategic Planning}

Few banks disclose that they have some annual green targets for which both strategic plans and budgets are duly approved. Each year they determine a set of green yearly targets. They also develop different means of materializing the actions, monitoring, supervision, evaluating the achievement, promotion and training/ awareness development programs. One of the banks disclosed its green banking budget (Appendix: Table 1) quarter by quarter highlighting the areas of green banking in its green banking report. Another bank has set its green strategic planning with the target of reduction of (a) 5\% electricity, gas, and fuel consumption, (b) 10\% paper consumption, (c) $5 \%$ GHG emission, and (d) $5 \%$ electronic bills.

\subsection{Green Banking Products}

The study reveals that very few banks have developed their green banking products in a comprehensive way. One of the banks disclosed its green baking products (Appendix: Table 2) categorically (such as Solar Cooker assembly Plant, PET Bottle Recycle Plant, Used Paper recycle plant for Paper production, LED Bulb/ Tube Light assembly Plant, Censored power switch assembly plant for electricity savings, Poultry \& Dairy based Large scale Bio-Gas Plant, Hazardous Waste management/treatment, Compressed Blok Brick production plant(Non Fire Brick, Waste Water \& Sewage Water Treatment Plant etc. ) in its green baking report in line with the framework of central bank of Bangladesh, Bangladesh Bank.

\section{Discussion}

The study reveals that still green banking is not being practiced comprehensively and in a meaningful fashion. In fact, the practice of green banking is really in its infancy in Bangladesh and they are far behind their counterparts from developed countries (Masukujjaman \& Aktar, 2014). The study finds that only very few commercial banks are doing in-house environment management in volume and scale and contributing significantly to the sustainable 
financing. In line with the findings of Hossain et al. (2016), the study reveals many of the sample banks only presented a general statement without having detailed information with specific quantitative information. The poor practice of green banking is reflected through poor fund (0.04\%) allocation for solid waste management. Currently, solid waste is causing severe multidimensional challenge to the environment of developing countries (Guerrero, Maas, \& Hogland, 2013) particularly in Bangladesh (Sujauddin, Hud, \& Hoque, 2008; Bhuiyan, 2010) such as pollution, health hazard, water sewerage problem, mosquito generation etc. It is to note that the quantity of solid waste generation was $1.3 \mathrm{~kg} /$ household $/$ day and $0.25 \mathrm{~kg} /$ person/day in Chittagong (Sujauddin, Huda, \& Hoque, 2008) of Bangladesh. Despite generating huge amount of solid wasted, the study reveals that the financial institution and banks are not focusing on the solid waste management. In this regard one Banker replied that;

Solid management is the major responsibility of City Corporation. If corporation seeks our cooperation we are ready to help them through financing their projects. As a financier we cannot finance unless and until someone has asked for financing such kind of projects. The entrepreneurs should come forward with comprehensive and realistic project and then we will consider financing. (Interviewee 5, Deputy managing director, and Head of corporate investment, Private commercial bank)

With a view to knowing the roles of City Corporation and to settle the debate the researchers consulted with the representative of City Corporation. Interestingly, the representative cautiously and sagaciously provided his views and opinion. He replied that;

The situation of solid waste management is an issue of concerned within the city. And this problem can be solved properly and permanently only when every single dweller is conscious and sincere in controlling it. However, we are paying our attention to the issues more carefully (Interviewee 2, Councilor, City Corporation)

Furthermore, since practice of green banking is a policy issue and a great concern of the central bank of Bangladesh, Bangladesh Bank, we also sought opinion from them. Interestingly, the respondent of central bank of Bangladesh, Bangladesh bank replied they have been working with sincerity to promote green banking practices and accordingly the scenario is changing gradually. According to the own words of the representative;

We have provided policy framework addressing the different issues relating to green banking. However, the reports show that the banks have invested very small amount of money in different areas and products of green banking including solid waste management. We are concerned about this issue. We will investigate the issue and take some pragmatic steps in this regard. (Interviewee 3, GM, Bangladesh bank).

However, one very senior manager of a private commercial bank disagrees with the poor performance of green banking in Bangladesh and expresses his satisfaction on the current status as well as future prospect of it. According to him the concept is very comprehensive and it has different dimensions and wider scope. The banker defends his position sating that,

Of course, green banking is being practiced with limited scale and volume in Bangladesh. However, the situation is gradually improving and bank as a financier is playing role and will play more active and vibrant roles (Interviewee 1, Executive vice president and Head of sustainable banking, Private commercial bank)

Although banks and NBFIs do not impact the environment greatly through their own internal operations, yet they have substantial effects on environment indirectly through their customers' activities. The banking sector is one of the major sources of financing industrial projects such as paper, steel, chemicals, cement, power, fertilizers, textiles, etc., which are the sources of highest carbon emission. Therefore, as an intermediary, the banking sector can play very important and pivotal role between economic development and environmental protection by motivating and promoting socially responsible and environmentally sustainable investment. This is green banking which can transform the conventional banks to ethical banks, environmentally responsible banks, socially responsible banks, or sustainable banks which responsibly deal with people, planet and profit, social and community benefit, ensuring allocation efficiency, financial \& social stability and responsible to ethical, human and social commitment. They are to use their resources with responsibility avoiding wastage and giving priority to environment and the society.

\section{Conclusion and policy Recommendations}

Like in many other countries, environmental degradation is very much visible in Bangladesh. It is manifested through destruction of wetlands, deforestation, depletion of soil nutrients, high level of air and water pollution, improper disposal of medical, industrial, and house-hold wastages, loss of biodiversity and loss of open space etc. As socially responsible corporate citizens, Bangladeshi banks have a major role and responsibility in supplementing government efforts towards substantial reduction in carbon emission. The wave of green banking has touched banks and non-banking financial institutions (NBFIs) in Bangladesh. However, they are still at their 
infancy in practicing green banking. They practice green banking/financing more or less following the guidelines prescribed by Bangladesh Bank, the central bank of Bangladesh.

To aid the reduction of external carbon emission, green banking finances green technology and pollution reducing projects. In fact, the motto of each and every bank in the country should be never to invest in the environmentally threat project and thereby protecting environment as main goal and minimizing credit risk, legal risk, and reputation risk as by-products.

Bangladesh Bank, the central bank of Bangladesh, emphasizes on environment and environment-friendly project. In this regard, as the guardian of the banks it should monitor the performance of green banking and financing and ranking them as per their green banking practices and to promote green banking by rewarding the best practicing banks and NBFIs. The environmental ministry, industry ministry, the media and NGOs, City corporations, and civil society should play effective and vibrant roles for developing awareness among all the stakeholders about green baking and its benefits. Indeed, green banking initiative is not only a holistic approach but also a multi-stake holder approach. Thus, its successful and fruitful execution is possible when combined and coordinated efforts of all concerned are being made.

\section{References}

Ahmad, F., Zayed, N. M., \& Harun, M. (2013). Factors behind the adoption of green banking by Bangladeshi commercial banks. ASA University Review, 7(2).

Ahsan, M. K., \& Uddin, M. S. (2015). Justification of Present Status of Green Banking in Bangladesh. Asian Accounting \& Auditing Advancement. from https://scholar.google.com/scholar?hl=en\&as_sdt=2005\&sciodt=0\%2C5\&cites=16398071574107614108\& scipsc $=\& \mathrm{q}=\mathrm{Ahsan} \% 2 \mathrm{C}+\mathrm{M} .+\mathrm{K} . \% 2 \mathrm{C}+\% 26+\mathrm{Uddin} \% 2 \mathrm{C}+\mathrm{M} .+\mathrm{S} .+\% 282015 \% 29 .+\mathrm{Justification}+\mathrm{of}+$ Present $+\mathrm{S}$ tatus+of+Green+Banking+in+Bangladesh.+Asian+Accounting+\%26+Auditing+Advancement.\&btnG=

Anonymous. (n. d.). Information transparency as a differentiation factor of ethical banking in Europe: A radical affinity index approach. The IUP Journal of Bank Management, 7(3), 7-22.

Bahl, S. (2012). Green banking-The new strategic imperative. Asian Journal of Research in Business Economics and Management, 2(2), 176-185.

Berg, B. L., \& Lune, H. (2012). Qualitative Research Methods for the Social Sciences (8th ed.). Boston: Pearson.

Bhardwaj, B. R., \& Malhotra, A. (2013). Green banking strategies: Sustainability through corporate entrepreneurship. Greener Journal of Business and Management Studies, 3(4), 180-193. https://doi.org/10.15580/GJBMS.2013.4.122412343

Bhuiyan, S. H. (2010). A crisis in governance: Urban solid waste management in Bangladesh. Habitat International, 34(1), 125-133. https://doi.org/10.1016/j.habitatint.2009.08.002

Bihari, S. C. (2010). Green banking-towards socially resonsible banking in India. International Journal of Business Insights \& Transformation, 4(1), 82-87

Bihari, S. C., \& Pandey, B. (2015). Green banking in India. Journal of Economics and International Finance, 7(1), 1-17. https://doi.org/10.5897/JEIF2014.0599

Dharwal, M., \& Agarwal, A. (2013). Green Banking: An Innovative Initiative for Sustainable Development. ACCMAN Institute of Management Article. Retrieved from https://scholar.google.com/scholar?hl=en\&as_sdt=0\%2C5\&q=Dharwal\%2C+M.\%2C+\%26+Agarwal\%2C+ A.+\%282013\%29.+Green+Banking\%3A+An+Innovative+Initiative+for+Sustainable+Development.+\&btn $\mathrm{G}=$

Guerrero, L. A., Maas, G., \& Hogland, W. (2013). Solid waste management challenges for cities in developing countries. Waste management, 33(1), 220-232. https://doi.org/10.1016/j.wasman.2012.09.008

Hoepner, A. G., \& Wilson, J. O. (2010). Social, environmental, ethical and trust (SEET) issues in banking: An overview. Retrieved from http://papers.ssrn.com/sol3/papers.cfm?abstract_id=1686240

Hossain, D. M., Momen, A., Al Bir, A. T. S., \& Tarique, K. M. (2016). Disclosure of Green Banking Issues in the Annual Reports: A Study on Bangladeshi Banks. Middle East Journal of Business, 11(1), 19-30. https://doi.org/10.5742/MEJB.2015.92758

Islam, M. S. (2014). Green Banking in Bangladesh: How Much Implemented by the Practitioners? Abasyn University Journal of Social Sciences, 7(2), 189-210. 
Islam, M. S., \& Das, P. C. (2013). Green banking practices in Bangladesh. IOSR Journal of Business and Management (IOSR-JBM), 8(3), 39-44. https://doi.org/10.9790/487X-0833944

Islam, M. S., \& Hasan, M. M. (2015). Reasons behind the Practices of Green Banking by Commercial Banks: A case study on Bangladesh. European Journal of Business and Management, 7(22), 51-59.

Islam, T., Sharmeen, K., \& Rahman, S. (2014). Adopting Green: from the Perspective of Private Commercial Banks in Bangladesh. Proceedings of Annual Shanghai Business, Economics and Finance Conference 3-4 November.

Krippendorff, K. (2004). Content Analysis: An Introduction to Its Methodology (2nd ed.). Thousand Oaks, CA: Sage.

Lalon, R. M. (2015). Green banking: Going green. International Journal of Economics, Finance and Management Sciences, 3(1), 34-42. https://doi.org/10.11648/j.ijefm.20150301.15

Masukujjaman, M., \& Aktar, S. (2014). Green banking in Bangladesh: A commitment towards the global initiatives. Journal of Business and Technology (Dhaka), 8(1-2), 17-40. https://doi.org/10.3329/jbt.v8i1-2.18284

Muhamat, A. A., \& Nizam bin Jaafar, M. (2010). The development of ethical banking concept amongst the Malaysian Islamic banks. Retrieved from https://scholar.google.com/scholar?hl=en\&as_sdt=0\%2C5\&q=Muhamat\%2C+A.+A.\%2C+\%26+Nizam+bi $\mathrm{n}+\mathrm{Jaafar} \% 2 \mathrm{C}+\mathrm{M} .+\% 282010 \% 29 .+$ The+development+of+ethical+banking+concept+amongst+the+Malaysi an+Islamic+banks\&btnG=

Nisha, N. (2016). Green investments and returns: A developing country perspective. Measuring Sustainable Development and Green Investments in Contemporary Economies.

Rahman, M. M., Ahsan, M. A., Hossain, M. M., \& Hoq, M. R. (2015). Green banking prospects in Bangladesh. Asian Business Review, 2(2), 59-6. https://doi.org/10.18034/abr.v2i2.305

Rifat, A., Nisha, N., Iqbal, M., \& Suviitawat, A. (2016). The role of commercial banks in green banking adoption: A Bangladesh perspective. International Journal of Green Economics, 10(3-4), 226-251. https://doi.org/10.1504/IJGE.2016.081906

Roy, M. K., Salam Sarker, M., \& Parvez, S. (2015). Sustainability in Banking Industry: Which way to move? ASA University Review, 9(2), 53-69.

Sahoo, P., \& Nayak, B. P. (2008). Green banking in India. Indian Economic Journal, 55(3), 82-98. https://doi.org/10.1177/0019466220070306

Shakil, M. H., Azam, M. K. G., \& Raju, M. S. (2014). An evaluation of green banking practices in Bangladesh. European Journal of Business and Management, 6(31), 8-16.

Shaumya, K., \& Arulrajah, A. A. (2016). Measuring Green Banking Practices: Evidence from Sri Lanka. Paper presented in the $13^{\text {th }}$ International Conference on Business Management 2016. https://doi.org/10.2139/ssrn.2909735

Sujauddin, M., Huda, S. M. S., \& Hoque, A. R. (2008). Household solid waste characteristics and management in Chittagong, Bangladesh. Waste Management, 28(9), 1688-1695. https://doi.org/10.1016/j.wasman.2007.06.013

Ullah, M. M. (2013). Green Banking in Bangladesh-A Comparative Analysis. World Review of Business Research, $3(4), 74-83$.

United Nations Environment Programme. (2014). About GEI:UNEP. Retrieved from http://www.unep.org/greeneconomy/aboutgei/whatisgei/tabid/29784/default.aspx

Weber, O. (2010). Social banking: Products and services. https://doi.org/10.2139/ssrn.1621822

Weber, O., Hoque, A., \& Ayub Islam, M. (2015). Incorporating environmental criteria into credit risk management in Bangladeshi banks. Journal of Sustainable Finance \& Investment, 5(1-2), 1-15. https://doi.org/10.1080/20430795.2015.1008736

Weber, R. P. (1990). Basic content analysis Sage university papers series. Quantitative Applications in the Social Sciences. Retrieved from http://catdir. loc.gov/catdir/enhancements/fy0655/90061019-d.html 


\section{Appendix}

EDD $=$ Environmental and social due diligence

Table 1.Green banking budget of a bank for the year 2017

\begin{tabular}{lccccc}
\hline Areas of green banking & $\begin{array}{c}\mathbf{1}^{\text {st }} \text { quarter } \\
(\text { million Taka) }\end{array}$ & $\begin{array}{c}\mathbf{2}^{\text {nd }} \text { quarter } \\
(\text { million Taka) }\end{array}$ & $\begin{array}{c}\mathbf{3}^{\text {rd }} \text { quarter } \\
(\text { million Taka) }\end{array}$ & $\begin{array}{c}\mathbf{4}^{\text {th }} \text { quarter } \\
\text { (million Taka) }\end{array}$ & $\begin{array}{c}\text { Total } \\
\text { (million Taka) }\end{array}$ \\
\hline Direct green investment & $6,238.00$ & $6,303.00$ & $6,178.00$ & $6,223.00$ & $\mathbf{2 4 9 4 2}$ \\
Indirect green investment & $27,975.00$ & $24,455.00$ & $25,965.00$ & $23,625.00$ & $\mathbf{1 0 2 0 2 0}$ \\
Climate risk fund & 75.00 & 15.00 & 60.00 & 10.00 & $\mathbf{1 6 0}$ \\
Green training & 0.33 & 0.28 & 0.28 & 0.23 & $\mathbf{1 . 1 2}$ \\
Green marketing & 49.00 & 50.50 & 48.50 & 59.00 & $\mathbf{2 0 7}$ \\
\hline
\end{tabular}

Table 2. Green banking products of banks and NBFIs in Bangladesh

\begin{tabular}{|c|c|c|c|}
\hline SL & Product name & SL & Product name \\
\hline \multirow[t]{4}{*}{1} & Solar Home System & 20 & Censored power switch assembly plant for electricity savings \\
\hline & Solar Micro/Mini Grid & & \\
\hline & Solar Irrigation Pump System & & \\
\hline & iii. Solar Photovoltaic (PV) Assembly Plant & & \\
\hline \multirow[t]{4}{*}{2} & Bio-Gas Plant & 21 & Improved Cook Stove (ICS)/ICS Renewable/Hybrid Cook Stove \\
\hline & i. Integrated Cattle Rearing \& Bio-Gas Plant installation & & \\
\hline & Organic Manure from Slurry & & \\
\hline & iii. Medium Size Bio-Gas Plant & & \\
\hline \multirow[t]{3}{*}{3} & Biological ETP & 22 & Replacement in industry /Factory inefficiency by energy savings \\
\hline & i. Integrated ETP Technology of Biological \& Chemical & & lighting system, efficient electronic equipment, energy efficient \\
\hline & Chemical ETP transformation in as (Kha) nos & & boiler by Energy Audit Report \\
\hline 4 & $\begin{array}{l}\text { Old kiln of Calcium Carbonate Transformation in New kiln } \\
\text { (Lime Kiln) }\end{array}$ & 23 & $\begin{array}{l}\text { Methane recovery \& production of electricity from Municipality } \\
\text { wastage }\end{array}$ \\
\hline 5 & Vermicompost (কঁঁচোকম্পুস্টসার) & 24 & Windmills electricity Plant \\
\hline 6 & Water Electricity Plant(Pico, Micro, Mini) & 25 & Hazardous Waste management / treatment \\
\hline 7 & PET Bottle Recycle Plant & 26 & Fecal Sludge (গাঁদ) management \& processing \\
\hline 8 & Solar Betray Recycle Plant & 27 & Waste Water \& Sewage Water Treatment Plant \\
\hline 9 & LED technology based Bulb production Plant & 28 & Burning Oil Production from Tier (Pyrolysis Process) \\
\hline 10 & $\begin{array}{l}\text { Reduce Carbon in Hybrid Hoffman Kiln (HHK)/Tunnel Kiln } \\
\text { /Equivalent Plant installation }\end{array}$ & 29 & Compresed Blok Brick production plant(Non Fire Brick) \\
\hline 11 & $\begin{array}{l}\text { Bio-Moss based Big Size Bio-Gas Plant (Agriculture Wastage, } \\
\text { Rice Ban, Sugar Can straw or wastage, Crops unused part used } \\
\text { as raw materials) }\end{array}$ & 30 & Foam -Concrete Block Production Plant(Non Fire Brick) \\
\hline 12 & Poultry \& Dairy based Large scale Bio-Gas Plant & 31 & Used Paper recycle plant for Paper production \\
\hline 13 & 01 (One) Mega watt or more higher capacity Solar PV Plant & 32 & Plastic Wastage (PVC/PP/LDPE/HDPE/PS) recycle Plant \\
\hline 14 & Solar Cooker assembly Plant & 33 & $\begin{array}{l}\text { Reprocessing of Bagged plant (Natural raw materials: Bamboo } \\
\text { etc.) }\end{array}$ \\
\hline 15 & Solar Water Hitter assembly plant & 34 & $\begin{array}{l}\text { Reprocessing of Non-Oven polypropylene neat \& bagged } \\
\text { production plant }\end{array}$ \\
\hline 16 & Solar Air Hitter \& Cooling System assembly Plant & 35 & Pam oil Production with Energy Efficiency Plant \\
\hline 17 & Cold Storage of Solar Power Plant & 36 & $\begin{array}{l}\text { To drink Surface water treatment \& supply plant by using solar } \\
\text { pump }\end{array}$ \\
\hline 18 & Production of Organic Manure from Municipality Wastage & 37 & $\begin{array}{l}\text { Green Industry (Uses of natural light, Water, wind \& energy } \\
\text { efficiency technology) }\end{array}$ \\
\hline 19 & LED Bulb/ Tube Light assembly Plant & 38 & $\begin{array}{l}\text { Improving Working Environment \& security at Textile \& Fabric } \\
\text { industry }\end{array}$ \\
\hline
\end{tabular}

Source: compiled by the authors on the basis of annual reports and corporate websites. 


Phase 01
(Deadline: 31 December, 2011)
1.1 Policy formulation and
governance
1.2 Incorporation of
environmental risk in credit risk
management (CRM)
1.3 Initiating in-house
environment management
1.4 Introducing green house
finance
1.5 Creation of climate risk
fund
1.6 Introducing green marketing
1.7 Online banking
1.8 Supporting employee
training, consumer awareness
and green event
1.9 Disclosure and reporting of
green banking activities

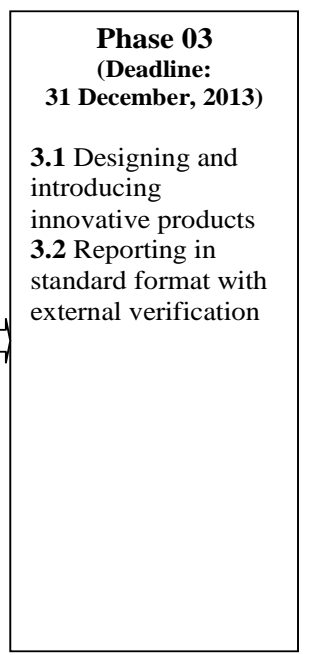

Figure 1. Bangladesh bank's policy framework for green banking

Source: Annual report of Bangladesh Bank, 2012.

\begin{tabular}{|ll|}
\hline i. & Renewable Energy \\
ii. & Energy Efficient Technology \\
iii. & Solid Waste Management \\
iv. & Liquid Waste Management \\
v. & Alternative Energy Plant \\
vi. & Non-Fire Block Brick Manufacturing Project \\
vii. & Recycling Plant and Recyclable Product Manufacturing Plant \\
viii. & Improvement of Brick Kiln Efficiency \\
\hline
\end{tabular}

Figure 2. Bangladesh bank's suggested green financing schemes

\section{Copyrights}

Copyright for this article is retained by the author(s), with first publication rights granted to the journal.

This is an open-access article distributed under the terms and conditions of the Creative Commons Attribution license (http://creativecommons.org/licenses/by/4.0/). 